A. Fedorchuk, Master Student

Taras Shevchenko National Univercity of Kyiv, Kyiv, Ukraine

\title{
PROOVING IN CASES OF DISCRIMINATION IN THE FIELD OF LABOUR
}

This article reveals the particularities of proof in cases of discrimination in the field of labour. On the basis of the analyzed special literature, legislation in force, international labour standards and positive legislative experience of foreign countries, specific proposals and recommendations on the improvement of proof mechanisms are made. Special attention is paid to the shift of the burden of proof and the formation of the "presumption of discrimination" concept, saying that in certain cases, when there is evidence prima facie justifying the allegations, the burden of proving the absence of discrimination can be shifted to the employer. It is determined that in order to recognize the fact of discrimination, it is first necessary to establish two circumstances. First, there is the difference in attitude towards employees. Second, this distinction must be based on prohibited features. The case law of the European Court of Human Rights on discrimination in the field of labor is analyzed and the main positions of the court on establishing the fact of discrimination are highlighted. Types of evidence in cases of discrimination in the field of labor are considered. In cases of discrimination, written evidence, testimony of witnesses, physical evidence, expert opinions, etc. are used. The list of admissible types of evidence may vary from country to country. To solve this problem, it is proposed to expand the range of admissible types of evidence (testing, statistics, audio and video recordings, questionnaires). Requirements for the conditions of admissibility of evidence in cases of discrimination in the field of labor are proposed. Special attention is paid to the position of the European Court of Justice. The article also describes the national mechanism for proving discrimination in the field of labor. It is also proposed to amend national legislation to improve the mechanism for proving discrimination.

Key words: discrimination, proof, burden of proof, evidence, equality, international labor standards.

Bulletin of Taras Shevchenko National University of Kyiv. Legal Studies, 2020; 3 (114): 63-68

удк: 342.95

DOI: https:doi.org/10.17721/1728-2195/2020/5.115-13
ISSN 1728-2195

(C) Taras Shevchenko National University of Kyiv, Publishing center "Kyiv University", 2020

К. Яблуновська, асп. ORCID ID: 0000-0002-5553-2480

Київський національний університет імені Тараса Шевченка, Київ, Україна

\section{ЄВРОПЕЙСЬКІ СТАНДАРТИ ПРАВА НА СВОБОДУ ПЕРЕСУВАННЯ ТА ПРАВА НА ВІЛЬНИЙ ВИБІР МІСЦЯ ПРОЖИВАННЯ}

Статтю присвячено визначенню системи стандартів права на свободу пересування та права на вільний вибір місця проживання, чинних в Європейському Союзі.

У дослідженні використано широкий спектр загальнонаукових та спеціально-юридичних методів і прийомів наукового пізнання, зокрема: порівняльно-правовий, системно-структурний $і$ формально-догматичний методи, а також такі прийоми наукового пізнання, як аналіз і синтез, індукція та дедукція, класифікація тощо.

Унаслідок виконаного дослідження автором обгрунтовано наукову позицію про те, що наявна в Україні система стандартів права на свободу пересування та права на вільний вибір місия проживання лише частково відповідає стандартам прав, які існують у країнах-членах ЄС. Відмінність цих стандартів виявляється на рівні специфріки правового регулювання реалізації названих прав людини у членів сімї громадян країн-членів $€ С$, а також цілей для впровадження відповідних стандартів.

Приведення українських стандартів названих прав людини у відповідність до європейських аналогів передбачає нормотворчу діяльність публічної адміністрації. Джерелом такої нормотворчої роботи має стати базова Директива Європейського Парламенту та Ради 2004/38/ЄС "Про право громадян Союзу та членів їхніх сімей вільно пересуватися та проживати на території держав-членів, яка змінює Регламент 1612/68/ЄЕС та відміняє директиви 64/221/ЄEC, 68/360/ЄEC, 72/194/EEC, 73/148/ ЄEC, 75/34/ ЄEC, 75/35/ GEC, 90/364/ GEC, 90/365/ GEC ma 93/96/ ЄEC" (2004 p.).

Ефективність приведення українських стандартів права на свободу пересування та права на вільний вибір місця проживання до єөропейських аналогів значно підвищиться, якщо публічна адміністрація матиме еталони для відповідного правового регулювання. На наш погляд, таким еталоном можна вважати Allgemeine Verwaltungsvorschrift zum Freizügigkeitsgesetz/EU (AVV zum FreizügG/EU) (Загальне адміністративне уложення Закону про свободу пересування громадян), що створене відповідно до вказаної Директиви ЄС та інших юридичних актів ЄС, які регулюють свободу пересування та права на вільний вибір місця проживання на території Європейського Союзу.

Ключові слова: свобода пересування, вільний вибір місця проживання, права людини, стандарти, законодавство.

ВСтУП. Підписання Україною Угоди про асоціацію між Україною, з однієї сторони, та Європейським Союзом, Європейським співтовариством з атомної енергії та їхніми державами-членами, з іншої сторони [1], проголошення на рівні Основного Закону незворотності європейського курсу України [2] передбачає виконання українською стороною вимог, що $є$ передумовами набуття нею повноправного членства в Європейському Союзі. Однією з неодмінних умов такого членства $€$ адаптація законодавства України до законодавства Європейського Союзу. Для України це означає приведення власної правової системи у відповідність до асquis communautaire, тобто правової системи Європейського Союзу. Причому такий процес стосується не тільки тих юридичних актів $Є С$, які визначені у Додатках до Угоди про асоціацію. Звичайно, він охоплює всі юридичні акти ЄС, які $€$ обов'язковими для всіх країн-членів Європейського Союзу, зокрема й ті, що визначають європейські стандарти права на свободу пересування та права на вільний вибір місця проживання.
Водночас не варто забувати того, що нині юридичні акти $€ C$, зокрема регламенти $€ С$, директиви $€ С$ тощо відіграють виключно роль орієнтира для правотворчості суб'єктів публічної влади і насамперед для суб'єктів публічної адміністрації.

Однак євроінтеграційні прагнення України, подальший рух нашої країни до повноправного членства в ЄС обов'язково приведуть до необхідності адаптації законодавства України до законодавства ЄС й у частині стандартів права на свободу пересування та права на вільний вибір місця проживання, які втілені на рівні спеціальних директив ЄС і регламентів ЄС. Зважаючи на це, необхідно з'ясувати, які стандарти права на свободу пересування та права на вільний вибір місця проживання існують в Європі, а також те, якою мірою наявні в Україні стандарти названих прав людини відповідають цим стандартам. З'ясуванню цього питання i присвячено цю статтю.

Методологічною основою $€$ передусім порівняльноправовий метод дослідження, що дав змогу порівняти 
наявні в Україні стандарти права на свободу пересування та права на вільний вибір місця проживання зі стандартами цих прав, які існують у країнах-членах Європейського Союзу. Також використано системно-структурний і формально-догматичний методи дослідження. Крім того, важливе значення під час дослідження мали способи і прийоми наукового пізнання. Ідеться про аналіз і синтез, індукцію й дедукцію; класифікацію тощо.

Метою статті є дослідження європейських стандартів права на свободу пересування і права на вільний вибір місця проживання. Для досягнення вказаної мети дослідження необхідно розв'язати такі дослідницькі завдання: 1) визначити наявні європейські стандарти права на свободу пересування і права на вільний вибір місця проживання; 2) з'ясувати, наскільки чинні в Україні стандарти відповідають аналогам, що існують у країнах-членах $€ C$; 3) сорормулювати пропозиції щодо шляхів адаптації українських стандартів названих прав людини до європейських аналогів.

Аналіз останніх досліджень і публікацій. Досягнення визначеної мети дослідження передбачає аналіз значного кола наукових джерел.

Серед вітчизняних спеціалістів, які аналізували національні та європейські стандарти права на свободу пересування та права на вільний вибір місця проживання, можна назвати: О. Ф. Динько, І. Ю. Тарапаку, І. І. Голубку, Р. О. Стефранчука, О. В. Кохановську, Н. Г. Шукліну та ін. [3, 4, 5, 6, 7, 8].

До зарубіжних дослідників, які займалися відповідною проблематикою, належать: Я. Брезгер; Д. Хеселбер та ін. $[9,10]$.

Окреме пізнавальне і світоглядне значення мали праці вітчизняних і німецьких фахівців у галузі Загального адміністративного права, зокрема Р. С. Мельника, В. В. Галунька, М. Хармута та ін. $[11,12,13]$.

ВИКЛАД ОСНОВНОГО МАТЕРІАЛУ. СИстема європейських стандартів права на свободу пересування та права на вільний вибір місця проживання втілена, поперше, на рівні юридичних актів $€ С$, які рівною мірою стосуються будь-якої країни члена Європейського Союзу, по-друге, на рівні національного законодавства окремих країн-членів ЄС. Якщо говорити конкретніше, то в ЄC стандарти цих прав людини визначено у таких документах: Конвенції про захист прав людини й основоположних свобод (1950р.) [14]; Договорі про заснування Європейської Спільноти (1957р.) [15]; Паризькій хартії для нової Європи (1990р.) [16]; Хартії основних прав Європейського Союзу (2000р.) [17]; Директиві Європейського Парламенту та Ради 2004/38/ЄС "Про право громадян Союзу та членів їхніх сімей вільно пересуватися та проживати на території держав-членів, яка змінює Регламент 1612/68/ЄEC та відміняє директиви 64/221/ЄEC, 68/360/ЄEC, 72/194/EEC, 73/148/ ЄEC, 75/34/ ЄEC, 75/35/ ЄEC, 90/364/ ЄEC, 90/365/ ЄEC та 93/96/ ЄEC" (2004р.) [18]; Регламенті Комісії ЄEC № 1251/70 "Про право працівників залишатися на території держав-членів після здійснення там трудової діяльності" (1970р.) [19]; Регламенті ЄП та Ради ЄС (ЕО) № 810/2009 "Про затвердження Кодексу Спільноти 3 візових питань" (2009р.) [20]; Регламенті № 562/2006 $€ П$ та Ради ЄС "Про затвердження Кодексу Співтовариства про режим пересування осіб через кордони" (2006 р.) [21]; Регламенті ЄП та Ради ЄС 492/2011 "Щодо свободи пересування працівників у межах Союзу" (2001 р.) [22] тощо.

На рівні національного законодавства країн-членів $€ C$ стандарти права на свободу пересування та права на вільний вибір місця проживання визначені у таких документах: а) конституціях країн-членів $€ C$, напри- клад: у ст. 11 Основного Закону ФРН [23]; ст. 32 Конституції Литовської Республіки [24]; ст. 52 Конституції Республіки Польща [25] тощо; б) цивільних кодексах країн-членів ЄС, наприклад: § 7 та 8 Цивільного кодексу ФРН [26]; ст. 7 Цивільного закону Республіки Латвія [27] тощо; в) спеціальних законах. Зазначимо, що такі закони $є$ скоріше винятком та існують лише в окремих країнах-членах ЄС. Наприклад, у ФРН є спеціальний закон Freizügigkeitsgesetz / EU - FreizügG / EU (Федеральний закон про свободу пересування громадян) [28]. Крім того, є закони, які регулюють дотичні питання. Так, наприклад, у Німеччині існує Gesetz über die Angelegenheiten der Vertriebenen und Flüchtlinge (Федеральний закон про проблеми переміщених осіб і біженців) [29]; г) підзаконні нормативно-правові акти, прийняті публічною адміністрацією країн-членів ЄС. Звичайно, кожна країна має свою систему таких нормативноправових актів, які регулюють відносини між публічною адміністрацією та фрізичними особами з приводу реалізації їхнього права на свободу пересування та права на вільний вибір місця проживання. У Німеччині, наприклад, Федеральним урядом прийнято Algemeine Verwaltungsvorschrift zum Freizügigkeitsgesetz/EU (AVV zum FreizügG/EU) (Загальне адміністративне уложення Закону про свободу пересування громадян) [30]. Цей підзаконний нормативно-правовий акт, з одного боку, створений у чіткій відповідності з Директивою Європейського Парламенту та Ради 2004/38/€С "Про право громадян Союзу та членів їхніх сімей вільно пересуватися та проживати на території держав-членів, яка змінює Регламент 1612/68/ЄЕС та відміняє директиви 64/221/ЄEC, 68/360/ЄEC, 72/194/EEC, 73/148/ ЄEC, 75/34/ ЄEC, 75/35/ ЄEC, 90/364/ ЄEC, 90/365/ ЄEC та 93/96/ ЄEC" (2004р.) [18], а, з другого боку, він містить адміністративно-правові норми, які й регулюють відносини між публічною адміністрацією та фрізичними особами 3 приводу реалізації цих фундаментальних прав людини.

Варто зазначити, що не всі $з$ перелічених джерел права ЄС однаковою мірою визначають європейські стандарти права на свободу пересування та права на вільний вибір місця проживання. Так, Конвенція про захист прав людини й основоположних свобод (1950р.) [14]; Договір про заснування Європейської Спільноти (1957 р.) [15]; Паризька хартія для нової Європи (1990р.) [16]; Хартія основних прав Європейського Союзу (2000р.) [17] визначають такі стандарти лише у загальних рисах. Те саме стосується конституцій і цивільних кодексів країн-членів ЄС. Базовим юридичним актом ЄС, у якому визначено систему європейських стандартів названих прав людини, на наш погляд, $€$ Директива Європейського Парламенту та Ради 2004/38/€С "Про право громадян Союзу та членів їхніх сімей вільно пересуватися та проживати на території держав-членів, яка змінює Регламент 1612/68/€ЕС та відміняє директиви 64/221/ЄЕС, 68/360/ЄЕС, 72/194/EEC, 73/148/ EEC, 75/34/ EEC, 75/35/ EEC, 90/364/ ЄEC, 90/365/ ЄEC та 93/96/ ЄEC" (2004р.) [18]. Вона закріпила відмінну від української систему стандартів права на свободу пересування та права на вільний вибір місця проживання. Ця система складається 3 таких стандартів: 1) права на вихід та в'їзд; 2) права строкового проживання, яке містить: а) право проживання на термін до трьох місяців та б) право на проживання більше трьох місяців; 3) права на отримання посвідки на проживання членами сім'ї громадянина ЄС; 4) права на збереження можливості проживання на території країн-членів у випадку смерті та від'їзду громадянина Союзу; 5) права на проживання членів сім'ї у разі розірвання шлюбу або припинення зареєстровано- 
го партнерства; 6) права постійного проживання; 7) пільги для осіб, які більше не працюють у приймаючій державі-члені та членів їхніх сімей; 8) суміжних прав, до яких належать право членів сімей громадянина $€ C$, які незалежно від належності їх до певного громадянства мають право на працевлаштування у країнах-членах $€ C$ або на самозайнятість [18]. Отже, як видно з відповідної системи європейських стандартів названих прав людини, вони розраховані не тільки на громадян $€ С$, а й на членів їхніх родин, що $є$ нетиповим для українського законодавства, яке регламентує порядок реалізації цього права тільки стосовно певної категорії фрізичних осіб, зокрема щодо громадян України, іноземців, осіб без громадянства, а також біженців.

Нетиповою $є$ також аргументація стосовно того, що покладено в основу саме такої системи європейських стандартів права на свободу пересування та права на вільний вибір місця проживання. Так, у європейській літературі ми можемо знайти таке пояснення: "... встановлення таких стандартів має певні цілі, зокрема, надання громадянам $€ C$, а також членам їхніх сімей, трудовим-мігрантам:

- доступу до ринку праці ЄС;

- рівних із громадянами приймаючої країни умов праці;

- однакового підходу до оподаткування;

- доступу до навчання у країнах-членах ЄС;

- доступу до профрспілок;

- доступу до житла, освіти, освіти для своїх дітей тощо" [31].

Зазначимо, що запроваджена на рівні Директиви Європейського Парламенту та Ради 2004/38/€С "Про право громадян Союзу та членів їхніх сімей вільно пересуватися та проживати на території держав-членів, яка змінює Регламент 1612/68/ЄЕС та відміняє директиви 64/221/ЄEC, 68/360/ЄEC, 72/194/EEC, 73/148/ ЄEC, 75/34/ ЄEC, 75/35/ ЄEC, 90/364/ ЄEC, 90/365/ ЄEC та 93/96/ ЄEC" (2004р.) [18] система стандартів права на свободу пересування та права на вільний вибір місця проживання має визначальне значення для національного правового регулювання реалізації цих прав людини у країнах-членах ЄС. У цьому можна переконатися, аналізуючи, наприклад, законодавство Німеччини. Так, спеціальний закон Freizügigkeitsgesetz / EU FreizügG / EU (Федеральний закон про свободу пересування громадян) [28] та Allgemeine Verwaltungsvorschrift zum Freizügigkeitsgesetz/EU (AVV zum FreizügG/EU) (Загальне адміністративне уложення Закону про свободу пересування громадян) [30] не тільки повною мірою відповідає системі європейських стандартів названих прав людини, а й у окремих випадах розширює перелік таких стандартів. Наприклад, Allgemeine Verwaltungsvorschrift zum Freizügigkeitsgesetz/EU (AVV zum FreizügG/EU) (Загальне адміністративне уложення Закону про свободу пересування громадян) додатково до визначених у названий Директиві $€ С$ стандартів права на свободу пересування та права на вільний вибір місця проживання гарантує право на постійне проживання у Німеччині опікунів дітей померлого громадянина ФРН [30].

Оцінюючи рівень відповідності українських стандартів права на свободу пересування та права на вільний вибір місця проживання європейським стандартам названих прав людини, можна констатувати їхню часткову тотожність. Проте рівень такої відповідності незначний. Маємо підкреслити, що українські стандарти права на свободу пересування та права на вільний вибір місця проживання зумовлюються міжнародними договорами, зокрема: ст. 13 Загальної декларації прав людини [32], ст. 12 Міжнародного пакту про громадянські й політичні права [33], Протоколу № 4 до Конвенції про захист прав людини й основоположних свобод, який гарантує деякі права і свободи, не передбачені в Конвенції та у Першому протоколі до неї [34], що гарантують кожному: право вільно пересуватися; право обирати собі місце проживання у межах кожної держави; право покинути будь-яку країну, включно і свою власну; право повернутися у свою країну. Національне законодавство України закріплює відповідні міжнародні стандарти та конкретизує процедуру реалізації окремих елементів права на свободу пересування та права на вільний вибір місця проживання. У цій частині йдеться про положення: ст. 33 Конституції України [2]; ст. 313 Цивільного кодексу України [35], положення спеціального Закону України "Про свободу пересування та вільний вибір місця проживання в Україні" [36], Закону України "Про порядок виїзду з України і в'їзду в Україну громадян України" [37]; Закону України "Про правовий режим надзвичайного стану" [38]; Закону України "Про державну таємницю" [39] тощо. Водночас в Україні діє лише незначна частина суто європейських стандартів права на свободу пересування та права на вільний вибір місця проживання, які закріплені у ратифрікованих Україною Конвенції про захист прав людини й основоположних свобод [14] та Паризькій хартії для нової Європи [16]. Однак ці загальноєвропейські договори закріпили лише незначну частину європейських стандартів названих прав людини. Так, Конвенція про захист прав людини й основоположних свобод [14] не містить окремої статті, присвяченої захисту права на свободу пересування чи захисту праву на вільний вибір місця проживання. Такий захист здійснюється опосередковано через захист права на свободу й особисту недоторканність і захист права на повагу до приватного і сімейного життя, які закріплені у ст. 5 та 8 цієї Конвенції [14]. Що стосується Паризької хартії для нової Європи, то окремий ії̈ підрозділ, який має назву "Права людини, демократія, верховенство закону" містить положення, згідно з яким державиучасниці підтверджують той фракт, що кожна людина має право на свободу пересування та не може зазнавати дискримінації щодо реалізації цього та інших перелічених прав людини [16]. Однак ці положення мають скоріше загальний характер і не містять детального правового регулювання європейських стандартів права на свободу пересування та права на вільний вибір місця проживання, як це має місце у згадуваній нами Директиві Європейського Парламенту та Ради 2004/38/ЄС "Про право громадян Союзу та членів їхніх сімей вільно пересуватися та проживати на території державчленів, яка змінює Регламент 1612/68/€ЕС та відміняє директиви 64/221/ЄЕС, 68/360/ЄЕC, 72/194/EЕC, 73/148/ ЄEC, 75/34/ ЄEC, 75/35/ ЄEC, 90/364/ ЄEC, 90/365/ ЄEC та 93/96/ ЄEC" (2004р.) [18]. Отже, якщо зробити проміжний висновок, то можна констатувати, що стандарти права на свободу пересування та права на вільний вибір місця проживання, які існують в Україні, лише незначною мірою відповідають європейським стандартам цих прав людини.

Оцінюючи перспективи адаптації українських стандартів права на свободу пересування та права на вільний вибір місця проживання до європейських аналогів, маємо виходити з того, що входження України до складу ЄС приведе до обов'язковості юридичних актів ЄС, які визначають європейські стандарти названих фундаментальних прав людини. Таким чином, стандарти права на свободу пересування та права на вільний вибір місця проживання автоматично стануть обов'язковими також для України. На сьогодні ж такі акти не можна 
вважати повноцінними джерелами українського права. У цій частині ми цілковито поділяємо наукову позицію Р. С. Мельника, який зазначає: "... юридичні акти ЄС на сьогоднішній день $є$ юридичною основою (джерелом права) лише для правотворчої діяльності суб'єктів публічного адміністрування..." [11, с. 123]. Отже, публічна адміністрація України, формуючи або вдосконалюючи наявні українські національні стандарти цих фрундаментальних прав людини, може використовувати відповідні юридичні акти ЄС лише як еталон для їхнього вдосконалення та наближення до європейських аналогів. Водночас, зважаючи на те, що публічна адміністрація має діяти на підставі, у межах повноважень та у спосіб, що передбачені Конституцією та законами України, то необхідною умовою для цілісного запровадження європейських стандартів у законодавство Україні необхідні доповнення до Додатку Угоди про асоціацію.

Звичайно, така адаптація національних стандартів права на свободу пересування та права на вільний вибір місця проживання має знайти свій вияв у прийнятті на рівні законодавства України нових нормативноправових актів, які, з одного боку, будуть інструментом запровадження таких стандартів на національному рівні, a, з другого боку, регулюватимуть відносини між публічною адміністрацією та приватними особами з приводу реалізації права на свободу пересування та права на вільний вибір місця проживання останніми у сфрері публічного адміністрування. У цій частині варто звернути увагу на те, що важливе місце серед правового регулювання цих стандартів, поряд із нормами конституційного права, належить також нормам адміністративного права. Як справедливо звертає увагу Р. С. Мельник, серед переліку завдань, що стоять перед адміністративним правом, можна назвати, зокрема, конкретизацію конституційних прав і свобод приватних осіб, які можуть бути реалізовані ними у ссрері публічного адміністрування [11, с. 49]. Отже, правовідносини між публічною адміністрацією та приватними особами з приводу реалізації їхнього права на свободу пересування та права на вільний вибір місця проживання мають бути врегульовані відповідними джерелами адміністративного права. За еталон для нормотворчої роботи публічної адміністрації у частині наближення національних стандартів права на свободу пересування та права на вільний вибір місця проживання до європейських аналогів ми пропонуємо взяти Allgemeine Verwaltungsvorschrift zum Freizügigkeitsgesetz/EU (AVV zum FreizügG/EU) (Загальне адміністративне уложення Закону про свободу пересування громадян). Такий вибір є невипадковим, адже цей документ, з одного боку, якісно регулює відносини між публічною адміністрацією та приватними особами з приводу реалізації належних їм прав на свободу пересування та вільний вибір місця проживання, а, з другого боку, його створено у чіткій відповідності з юридичними актами $€ C$, які визначають стандарти названих прав на рівні $€ C$.

ВИСНОВКИ. Проведене дослідження дає змогу зробити такі висновки.

1. Констатовано, що наявна в Україні система стандартів права на свободу пересування та права на вільний вибір місця проживання лише частково відповідає стандартам прав, які існують у країнах-членах $€ С$. Відмінність цих стандартів виявляється на рівні специфріки правового регулювання реалізації названих прав людини у членів сім'ї громадян країн-членів ЄС. Крім того, система європейських стандартів указаних прав людини визначається певними цілями, зокрема: доступу до ринку праці ЄС; рівних із громадянами приймаючої країни умов праці; однакового підходу до оподатку- вання; доступу до навчання у країнах-членах $€ C$; доступу до профспілок тощо.

2. Приведення українських стандартів названих прав людини у відповідність до європейських аналогів передбачає нормотворчу діяльність публічної адміністрації. Джерелом такої нормотворчої роботи має стати базова Директива Європейського Парламенту та Ради 2004/38/€С "Про право громадян Союзу та членів їхніх сімей вільно пересуватися та проживати на території держав-членів, яка змінює Регламент 1612/68/ЄЕС та відміняє директиви 64/221/ЄEC, 68/360/ЄEC, 72/194/EEC, 73/148/ ЄEC, 75/34/ ЄEC, 75/35/ ЄEC, 90/364/ ЄEC, 90/365/ ЄEC та 93/96/ ЄEC" (2004 р.).

3. Ефективність приведення українських стандартів права на свободу пересування та права на вільний вибір місця проживання до європейських аналогів значно підвищиться, якщо публічна адміністрація матиме еталони відповідного регулювання відносин. На наш погляд, таким еталоном можна вважати Allgemeine Verwaltungsvorschrift zum Freizügigkeitsgesetz/EU (AVV zum FreizügG/EU) (Загальне адміністративне уложення Закону про свободу пересування громадян), адже воно створене у чіткій відповідності з указаною Директивою $€ C$ та іншими юридичними актами ЄС, які регулюють свободу пересування та права на вільний вибір місця проживання на території Європейського Союзу.

\section{Список використаних джерел}

1. Угода про асоціацію між Україною, з однієї сторони, та Європейським Союзом, Європейським співтовариством з атомної енергії їхніми державами-членами, з іншої сторони : Закон України від 16 вересня 2014 р. // Офріційний вісник України. - 2014. - № 75. - Ст. 83.

2. Конституція України // Відомості Верховної Ради України. 1996. - № 30. - Ст. 141.

3. Динько О. Ф. Зміст і гарантії забезпечення реалізації свободи пересування людини та громадянина в Україні : дис. ... канд. юрид. наук / О. Ф. Динько. - К. , 2003. - 220 с.

4. Тарапака І. Ю. Адміністративно-правове регулювання свободи пересування та вільного вибору місця проживання в Україні : дис. канд. юрид. наук / І. Ю. Тарапака. - О. , 2016. - 238 с.

5. Голубка І. І. Конституційні права на свободу пересування та вільний вибір місця проживання в Україні та країнах ЄС: порівняльноправовий аналіз : дис. ... канд. юрид. наук / І. І. Голубка. - Ужгород, 2016. -240 c.

6. Стефанчук Р. О. Особисті немайнові права фрізичних осіб у цивільному праві : автореф. дис. ... д-ра юрид. наук: 12.00.03 / Р. О. Стефанчук ; Ін-т держави і права ім. В. М. Корецького НАН України. - К. , 2007. -41 c.

7. Кохановська О. В. Проблеми реалізації права на свободу пересування в Україні і практика європейського суду / О. В. Кохановська // Часопис цивілістики. - 2015. - Вип. 18. - С. 157-163.

8. Шукліна Н. Г. Конституційно-правове регулювання прав і свобод людини й громадянина в Україні (проблеми теорії і практики): монографрія / Н. Г. Шукліна. - К. : Центр навч. літератури, 2005. - 424 с

9. Brezger J. Internationale Freizügigkeit als Menschenrecht / J. Brezger. - Frankfurt ; New York : Campus Verlag. - 2018. - $261 \mathrm{~s}$.

10. Hesselberger D. Das Grundgesetz: Kommentar für die politische / D. Hesselberger. - Bildung, 13. Aufl., Luchterhand, München/ Unterschleißheim, 2003. -207 s.

11. Мельник Р. С. Загальне адміністративне право в питаннях i відповідях : навч. посіб. / Р. С. Мельник. - К. : Юрінком Інтер, 2018. $308 \mathrm{c}$.

12. Адміністративне право України. Повний курс : підручник / В. Галунько, П. Діхтієвський, О. Кузьменко та ін. - Херсон : ОЛДІ-ПЛЮС, 2018. -446 c

13. Hartmut M. Allgemeines Verwaltungsrecht / M. Hartmut. München : C. H. Beck, 2004. $-853 \mathrm{~s}$.

14. Конвенція про захист прав людини й основоположних свобод від 4 листопада 1950 р. // Офіційний вісник України. - 1998. - № 13. Ст. 270.

15. Договір про заснування Європейської Спільноти від 25 березня 1957 p. URL: http://zakon2.rada.gov.ua/laws/show/994 017 (дата звернення: 13.07.2020)

16. Паризька хартія для нової Європи. URL: https://zakon.rada.gov.ua/ laws/show/995_058\#Text (дата звернення: 13.07.2020).

17. Хартія основних прав Європейського Союзу. URL: https://zakon.rada.gov.ua/laws/show/994_524\#doc_info (дата звернення: 13.07.2020).

18. Directive 2004/38/EC of the European Parliament and of the Council of 29 April 2004 on the right of citizens of the Union and their family members to move and reside freely within the territory of the Member States 
amending Regulation (EEC) No 1612/68 and repealing Directives 64/221/EEC, 68/360/EEC, 72/194/EEC, 73/148/EEC, 75/34/EEC 75/35/EEC, 90/364/EEC, 90/365/EEC and 93/96/EEC. Official Journal of the European Union. 2004. - L 158. - P. 77-123.

19. Regulation (EU) No 492/2011 of the European Parliament and of the Council of 5 April 2011 on freedom of movement for workers within the Union (codification) // Official Journal of the European Union. 2011 - L 141 -P. $1-12$.

20. Regulation (EC) № 810/2009 of the European Parliament and of the Council of 13 July 2009 establishing a Community Code on Visas (Visa Code). Official Journal of the European Union. 2009. - L 243. - P. 1-58.

21. Regulation (EC) № 562/2006 of the European Parliament and of the Council of 15 March 2006 establishing a Community Code on the rules governing the movement of persons across borders (Schengen Borders Code). Official Journal of the European Union. 2006. - L 105. - P. 1-32.

22. Regulation (EU) No 492/2011 of the European Parliament and of the Council of 5 April 2011 on freedom of movement for workers within the Union (codification). Official Journal of the European Union. 2011. - L 141. P. 1-12.

23. Grundgesetz für die Bundesrepublik Deutschland. URL: https://www.gesetze-im-internet.de/gg/BJNR000010949.html (дата звернення: 13.07.2020)

24. Lietuvos Respublikos Konstitucija issigaliojo $1992 \mathrm{~m}$. lapkričio $2 \mathrm{~d}$. Skelbta. URL: http://www3.Irs.It/home/Konstitucija/Konstitucija.htm (дата звернення: 13.07.2020).

25. Конституція Республіки Польща від 2 квітня 1997 p. URL: https://legalns.com/download/books/cons/poland.pdf (дата звернення: 13.07.2020).

26. Bürgerliches Gesetzbuch. URL: https://www.gesetze-im-internet.de/ $\mathrm{bgb/}$ (дата звернення: 13.07.2020).

27. Civillikums. URL: https://likumi.Iv/ta/id/225418-civillikums (дата звернення: 13.07.2020)

28. Freizügigkeitsgesetz. URL: https://www.gesetze-im-internet.de/ freiz_gg_eu_2004/ (дата звернення: 13.07.2020).

29. Gesetz über die Angelegenheiten der Vertriebenen und Flüchtlinge(Bundesvertriebenengesetz - BVFG). URL: https://www.gesetze-iminternet.de/bvfg/BJNR002010953.html (дата звернення: 13.07.2020).

30. Allgemeine Verwaltungsvorschrift zum Freizügigkeitsgesetz/EU (AVV zum FreizügG/EU). URL: http://www.verwaltungsvorschriften-iminternet.de/bsvwvbund_03022016_MI12100972.htm (дата звернення: 13.07.2020).

31. Freedom of movement in the EU. URL: https://www citizensinforma tion.ie/en/government in ireland/european government/european union/fre edom_of_movement_in_the_eu.html (дата звернення: 13.07.2020).

32. Загальна декларація прав людини від 10 грудня 1948 р. // Офіційний вісник України. - 2008. - № 93. - Ст. 3103

33. Міжнародний пакт про громадянські і політичні права від 16 грудня 1966 року. URL: http://zakon2.rada.gov.ua/laws/show/995_043 (дата звернення: 13.07.2020)

34. Протокол № 4 до Конвенції про захист прав людини і основоположних свобод, який гарантує деякі права і свободи, не передбачені в Конвенції та у Першому протоколі до неї від 16 вересня 1963 р. // Офіційний вісник України. - 2006. - № 32. - Ст. 2373.

35. Цивільний кодекс України від 16 січня 2003 р. / Верховна Рада України : офріц. вебпортал. URL: http://zakon.rada.gov.ua/laws/show/435-15 (дата звернення: 17.04.2020).

36. Про свободу пересування та вільний вибір місця проживання в Україні : Закон України від 11 грудня 2003 p. URL: http://zakon.rada.gov.ua/ laws/show/1382-15 (дата звернення: 13.07.2020).

37. Про порядок виїзду з України і в'їзду в Україну громадян України: Закон України від 21 січня 1994 р. № 3857-XII. URL: https://zakon.rada.gov.ua/laws/show/3857-12 (дата звернення: 13.07.2020).

38. Про правовий режим надзвичайного стану: Закон України від 16 березня 2000 р. № 1550-III. URL: https://zakon.rada.gov.ua/ laws/show/1550-14 (дата звернення: 13.07.2020).

39. Про державну таємницю: Закон України від 21.01.1994 р. № 3855 - XII. URL: https://zakon.rada.gov.ua/laws/show/3855-12 (дата звернення: 13.07.2020).

\section{References}

1. Uhoda pro asotsiatsiyu mizh Ukrayinoyu, z odniyeyi storony, ta Yevropeys'kym Soyuzom, Yevropeys'kym spivtovarystvom z atomnoy enerhiyi i yikhnimy derzhavamy-chlenamy, z inshoyi storony : Zakon Ukrayiny vid 16 veresnya 2014 roku. Ofitsiynyy visnyk Ukrayiny. 2014. № 75. P. 83 (in Ukrainian)

2. Konstytutsiya Ukrayiny. Vidomosti Verkhovnoyi Rady Ukrayiny. 1996. № 30. St. 141. (in Ukrainian).

3. Dyn'ko O.F. Zmist i harantiyi zabezpechennya realizatsiyi svobody peresuvannya lyudyny ta hromadyanyna $v$ Ukrayini [Contents and guarantees of ensuring the implementation of freedom of movement of man and citizen in Ukraine] Candidate's thesis. Kyyiv, 2003. 220 s. (in Ukrainian)

4. Tarapaka I.YU. Administratyvno-pravove rehulyuvannya svobody peresuvannya ta vil'noho vyboru mistsya prozhyvannya v Ukrayini [Administrative and legal regulation of freedom of movement and free choice of residence in Ukraine] Candidate's thesis. Odesa, 2016. 238 s. (in Ukrainian)

5. Holubka I. I. Konstytutsiyni prava na svobodu peresuvannya ta vil'nyy vybir mistsya prozhyvannya $v$ Ukrayini ta krayinakh YES: porivnyal'no-pravovyy analiz [Constitutional rights to freedom of movement and free choice of residence in Ukraine and EU countries: comparative legal analysis ] Candidate's thesis. Uzhhorod, 2016. 240 s. (in Ukrainian)

6. Stefanchuk R.O. Osobysti nemaynovi prava fizychnykh osib u tsyvil'nomu pravi [Personal non-property rights of individuals in civil law]: Doctor's thesis. In-t derzhavy i prava im. V. M. Korets'koho NAN Ukrayiny. Kyyiv, 2007. 41 s. (in Ukrainian)

7. Kokhanovs'ka O.V. Problemy realizatsiyi prava na svobodu peresuvannya v Ukrayini i praktyka yevropeys'koho sudu [Problems of realization of the right to freedom of movement in Ukraine and practice of the European court.]. Chasopys tsyvilistyky. Vyp. 18. 2015. S. 157-163 (in Ukrainian)

8. Shuklina N.H. Konstytutsiyno-pravove rehulyuvannya prav i svobod lyudyny y hromadyanyna $v$ Ukrayini (problemy teoriyi i praktyky) [Constitutional and legal regulation of human and civil rights and freedoms in Ukraine (problems of theory and practice)]. monohrafiya. Kyyiv: Tsentr navchal'noyi literatury, 2005. $424 \mathrm{~s}$. (in Ukrainian)

9. Brezger J. Internationale Freizügigkeit als Menschenrecht [International freedom of movement as a human right]. Campus Verlag Frankfurt/ New York, 2018. 261 s. (in German)

10. Hesselberger D. Das Grundgesetz: Kommentar für die politische Bildung [The Basic Law: Commentary for Political Education]. 13. Aufl., Luchterhand, München/Unterschleißheim 2003, 207 s. (in German)

11. Mel'nyk R. S. Zahal'ne administratyvne pravo $v$ pytannyakh vidpovidyakh [General administrative law in questions and answers] : navch. posib. Kyyiv: Yurinkom Inter, 2018. 308 s. (in Ukrainian)

12. Administratyvne pravo Ukrayiny. Povnyy kurs [Administrative law of Ukraine. Full course].: pidruchnyk / Halun'ko V., Dikhtiyevs'kyy P., Kuz'menko O., Stetsenko S. ta in. Kherson : OLDI-PLYUS, 2018. 446 s. (in Ukrainian)

13. Hartmut M. Allgemeines Verwaltungsrecht [General Administrative Law]. München: C.H. Beck, 2004. 853 s. (in German)

14. Konventsiya pro zakhyst prav lyudyny i osnovopolozhnykh svobod [Convention for the Protection of Human Rights and Fundamental Freedoms] vid 4 lystopada 1950 r. Ofitsiynyy visnyk Ukrayiny. 1998. № 13. St. 270. (in Ukrainian).

15. Dohovir pro zasnuvannya Yevropeys'koyi Spil'noty [Treaty establishing the European Community] vid 25 bereznya $1957 \mathrm{r}$ URL: http://zakon2.rada.gov.ua/laws/show/994_017 (acceed: 13.07.2020). (in Ukrainian)

16. Paryz'ka khartiya dlya novoyi Yevropy [Paris Charter for a New Europe]. URL: https://zakon.rada.gov.ua/laws/show/995_058\#Text (data zvernennya: 13.07.2020). (in Ukrainian)

17. Khartiya osnovnykh prav Yevropeys'koho Soyuzu [Charter of Fundamental Rights of the European Union]. URL: https://zakon.rada.gov.ua/ laws/show/994 524\#doc info (data zvernennya: 13.07.2020). (in Ukrainian)

18. Directive 2004/38/EC of the European Parliament and of the Council of 29 April 2004 on the right of citizens of the Union and their family members to move and reside freely within the territory of the Member States amending Regulation (EEC) No 1612/68 and repealing Directives 64/221/EEC, 68/360/EEC, 72/194/EEC, 73/148/EEC, 75/34/EEC, 75/35/EEC, 90/364/EEC, 90/365/EEC and 93/96/EEC. Official Journal of the European Union. 2004. L 158. P. 77-123 (in English)

19. Regulation (EU) No 492/2011 of the European Parliament and of the Council of 5 April 2011 on freedom of movement for workers within the Union (codification) // Official Journal of the European Union. 2011. L 141. P. 1-12 (in English)

20. Regulation (EC) № 810/2009 of the European Parliament and of the Council of 13 July 2009 establishing a Community Code on Visas (Visa Code). Official Journal of the European Union. 2009. L 243. P. 1-58. (in English).

21. Regulation (EC) № 562/2006 of the European Parliament and of the Council of 15 March 2006 establishing a Community Code on the rules governing the movement of persons across borders (Schengen Borders Code). Official Journal of the European Union. 2006. L 105. P. 1-32. (in English).

22. Regulation (EU) No 492/2011 of the European Parliament and of the Council of 5 April 2011 on freedom of movement for workers within the Union (codification). Official Journal of the European Union. 2011. L 141. P. 1-12 (in English)

23. Grundgesetz für die Bundesrepublik Deutschland [Basic Law for the Federal Republic of Germany]. URL: https://www.gesetze-iminternet.de/gg/BJNR000010949.html (acceed: 13.07.2020). (in German)

24. Lietuvos Respublikos Konstitucija [The Constitution of the Republic of Lithuania]jsigaliojo $1992 \mathrm{~m}$. lapkričio $2 \mathrm{~d}$. Skelbta.URL: http://www3.Irs.It/ home/Konstitucija/Konstitucija.htm(data zvernennya: 13.07.2020). (in Lithuanian)

25. Konstytutsiya Respubliky Pol'shcha [he Constitution of the Republic of Poland] vid 2 kvitnya 1997 roku. URL: https://legalns.com/download/ books/cons/poland.pdf (data zvernennya: 13.07.2020). (in Ukrainian)

26. Bürgerliches Gesetzbuch. URL: https://www.gesetze-im-internet.de/ bgb/ (acceed: 13.07.2020). (in German)

27. Civillikums. URL: https://likumi.Iv/ta/id/225418-civillikums(data zvernennya: 13.07.2020). (in Lithuanian).

28. Freizügigkeitsgesetz. URL: https://www.gesetze-im-internet.de/ freiz_gg_eu 2004/ (acceed: 13.07.2020). (in German)

29. Gesetz über die Angelegenheiten der Vertriebenen und Flüchtlinge(Bundesvertriebenengesetz - BVFG). URL: https://www.gesetze-iminternet.de/bvfg/BJNR002010953.html (acceed: 13.07.2020). (in German).

30. Allgemeine Verwaltungsvorschrift zum Freizügigkeitsgesetz/EU (AVV zum FreizügG/EU). URL: http://www.verwaltungsvorschriften-im- 
internet.de/bsvwvbund_03022016_Ml12100972.htm (acceed: 13.07.2020). (in German)

31. Freedom of movement in the EU. URL: https://www.citizensinformation.ie/ en/government_in_ireland/european_government/european_union/freedom _of_movement_in_the_eu.html (data zvernennya: 13.07.2020). (in English)

32. Zahal'na deklaratsiya prav lyudyny[Universal Declaration of Human Rights] vid 10 hrudnya 1948 r. Ofitsiynyy visnyk Ukrayiny. 2008. № 93. St. 3103 (in Ukrainian)

33. Mizhnarodnyy pakt pro hromadyans'ki i politychni prava [International Covenant on Civil and Political Rights] vid 16 hrudnya 1966 roku. URL: http://zakon2.rada.gov.ua/laws/show/995_043 (acceed: 13.07.2020). (in Ukrainian)

34. Protokol № 4 do Konventsiyi pro zakhyst prav lyudyny i osnovopolozhnykh svobod, yakyy harantuye deyaki prava i svobody, ne peredbacheni v Konventsiyi ta u Pershomu protokoli do neyi [Protocol No. 4 to the Convention for the Protection of Human Rights and Fundamental Freedoms, which guarantees certain rights and freedoms not provided for in the Convention and its First Protocol] vid 16 veresnya 1963 r. Ofitsiynyy visnyk Ukrayiny. 2006. № 32. St. 2373 (in Ukrainian)

35. Tsyvil'nyy kodeks Ukrayiny [Civil Code of Ukraine] vid 16.01.2003 r. / Verkhovna Rada Ukrayiny : ofits. veb-portal. URL: http://zakon.rada.gov.ua/ laws/show/435-15 (acceed: 13.07.2020). (in Ukrainian)

\section{K. Yablunovska, PhD Student}

Taras Shevchenko National University of Kyiv, Kyiv, Ukraine

\section{EUROPEAN STANDARDS FOR THE RIGHT TO FREEDOM OF MOVEMENT AND RIGHT TO FREE CHOICE OF RESIDENCE}

The article examines the system of standards for the right to freedom of movement and the right to free choice of residence that exist in the European Union.

A wide range of general and special legal methods and techniques of scientific knowledge are used, in particular: comparative law, systemstructural and formal-dogmatic research methods, as well as the methods of scientific knowledge (analysis and synthesis, induction and deduction, classification, etc).

As a result of the study, the author substantiates the scientific position that the existing system of standards for the right to freedom of movement and the right to free choice of residence in Ukraine only partially meets the standards of these rights that exist in EU member states. The difference between these standards exists on the level of specifics of legal regulation for the implementation of these human rights by family members of citizens of EU member states, as well as the goals pursued by the implementation of relevant standards.

Bringing Ukrainian standards of these human rights in line with European counterparts involves rule-making activities of public administration. The source of such rule-making should be Directive 2004/38/EC of the European Parliament and of the Council of 29 April 2004 on the right of citizens of the Union and their family members to move and reside freely within the territory of the Member States amending Regulation (EEC) No 1612/68 and repealing Directives 64/221/EEC, 68/360/EEC, 72/194/EEC, 73/148/EEC, 75/34/EEC, 75/35/EEC, 90/364/EEC, 90/365/EEC and 93/96/EEC (2004).

The effectiveness of bringing Ukrainian standards for the right to freedom of movement and the right to free choice of residence in line with EU standard will be increased significantly if the public administration has standards for legal regulation of relations between it and individuals in the process of exercising these rights by the latter. In our opinion, the Allgemeine Verwaltungsvorschrift zum Freizügigkeitsgesetz / EU (AVV zum FreizügG / EU) (General Administrative Code of the Law on Freedom of Movement of Citizens) can be considered as such a standard, as it is created in strict accordance with the EU Directive and other EU legal acts.

Key words: freedom of movement, free choice of place of residence, human rights, standards, legislation. 